\title{
畑雑草種子の発芽および出芽に及ぼす水分条件の影響*
}

\section{農林水産省農事試験場 野口勝可・中山兼徳}

嘎場において作物種子は一般に覆土されるので水分条 件が比較的安定しているのに対し, 雑草種子は概して発 生深叜が浅く ${ }^{9)}$, また, 極く地表面からも発生するため, 非常に不安定な環境条件におかれ, 多くの場合作物種子 に比べて低水分条件での出芽を余儀なくされている 一般に雑草は圃場における出芽が斉一でなく，そのこと が雑草防除を困難にしている一因となっているが，水分 条件の変動がそれを助長していると考えられる。畑雑草 防除技術を組み立てるためには, 雑草種子の出芽と水分 条件との関係を解明する必要がある。本研究は, 以上の ような観点から, 主要な畑雑草種子の水分条件に対する 反応について，作物や牧草種子と比較しながら検討した ものである。

\section{材料および方法}

[試験 1] 雑草としてメヒシバ, シロザ, オオイヌタ デ, スベリヒユ, カヤツリグサ，イヌビユ，才ヒシバ, 牧草としてローズグラス (カタンボラ), グリーンパニッ ク (雪印), 普通作物として陸稲 (タチミノリ), ラッカ セイ (アズマハンダチ), ダイズ (タチスズナリ), トウ モロコシ (交7号), グレインソルガム (NK 129), シ コクビェ (祖谷在来) を供試した。雑草と陸稲, ラッカ セイ,ダイズの種子は前年秋に農事試験場畑作部の圃場 （埼玉県北本市）で採種, 精選したものを用い, その他 は購入種子を用いた。シロザとオオイヌタデは試験に供 する前に, $5^{\circ} \mathrm{C}$ 湿潤条件で約 2 か月間貯蔵し休眠を打破 した。岩田ら ${ }^{3)}$ と同様の土壌水分調節装置をファイロン 製屋根の網室内に設置し，水面から地表までの高さがそ れぞれ $10 \mathrm{~cm}$ (1区), $30 \mathrm{~cm}$ (2区), $50 \mathrm{~cm}$ (3区), $60 \mathrm{~cm}$ ( 4 区), $70 \mathrm{~cm}$ ( 5 区) になるよらに火山灰上壤 を充填した。供試火山灰土壌は淡色黒ぼく土に属し，そ の物理性は固相率 $22.5 \%$, 粗砂 $14.6 \%$, 細砂 $43.6 \%$, シルト $28.6 \%$, 粘土 $13.2 \%$ である。種子はいずれも地 表面から $1 \mathrm{~cm}$ 層に播種した。播種粒数はラッカセイが 9 粒, ダイズ, トウモロコシが 16 粒, 陸稲, グレイン ソルガムが 50 粒, その他は 100 粒とし, 3 反復で実施し た。播種期は 1976 年 5 月 26 日で， 6 月 21 日まで試験 を実施した。試験期間中, 種子位置 $(0 \sim 1 \mathrm{~cm})$ の土壌 を 1 〜 日ごとに採取し, 含水比を測定した。
〔試験 2]直径 $9 \mathrm{~cm}$ または $14.5 \mathrm{~cm}$ のペトリ皿に沪 紙を敷き， $0 ， 0.2 ， 0.4 ， 0.6 ， 0.8$ モルに調整したグル コース溶液をそれぞれ $5 \sim 10 \mathrm{~m} l$ 注入し, 発芽床とした。 供試植物は試験 1 と同じで, ラッカセイは 25 粒, トゥ モロコシは 40 粒, ダイズ, グレインソルガムは 50 粒, その他は 100 粒置床し, グルコース溶液は $1 \sim 2$ 日ごと に更新した。試験は 1976 年 9 月 14 日から 10 月 6 日に わたり, 室内条件で 3 反復で実施した。なお,グルコー スモル濃度と浸透圧との関係は $0,0.2,0.4,0.6,0.8$ モルがそれぞれ $0,5 ， 11 ， 18 ， 25$ 気圧である。

[試験 3]直径 $10 \mathrm{~cm}$, 深さ $15 \mathrm{~cm}$ のプラスチック製 円筒に，含水比で $20 ， 25 ， 30 \%$ になるように水分条件 を調節した火山灰土壌を乾土重で $300 \mathrm{~g}$ あて充填した。 第 3 表に示した 7 種を供試し，10〜100 粒を $0 \sim 1 \mathrm{~cm}$ 層に播種, 水分が蒸発しないように透明なポリェチレン フィルムで被覆, 直射日光をさけてファイロン製屋根の 網室の中に設置した。試験は 1976 年 9 月 1 日から 21 日 まで， 3 反復で実施した。

[試験 4]火山灰土壤を充填し, 移動ハウスの中に設 置した $50 \mathrm{~cm}$ 平方の枠を用い, 次の試験区を設けた。

(1) $10 \mathrm{~mm}$ 灌水し直後に播種 (1区)

(2) 同 2 日後に播種 (2区)

(3) 同 4 日後に播種 ( 3 区)

(4) 同直後に擋拌し播種 (4区)

(5) 同 2 日後に擋拌し播種 ( 5 区)

(6) 同 4 日後に擋拌し播種 (6区)

(7) 無灌水で播種 ( 7 区)

(8) 同擋拌後播種 ( 8 区)

擋拌はレーキを用い， $0 \sim 2 \mathrm{~cm}$ 層を浅く行った。第 4 表に示した 5 種を供試， $1 ， 4 ， 7 ， 8$ 区は 1977 年 8 月 2 日， 2,5 区は 8 月 4 日， 3,6 区は 8 月 6 日に播種し た。播種粒数はダイズ, トウモロコシが 20 粒, 陸稲, グ レインソルガムが 50 粒, 雑草は 100 粒とし, 8 月 13 日 まで 3 反復で実施した。播種深度は雑草では $0 \sim 1 \mathrm{~cm}$ とし, 散播後種子がかくれる程度に覆土した。作物は狭 い溝をつくり, $1 \sim 2 \mathrm{~cm}$ 層に種子を落とし, 両側から おさえて覆土した。

*一部は日本雑草学会第 16 回講演会（昭和 52 年 4 月）において発表 


\section{試 験 結 果}

[試験 1 ] 地下水位の高さを変 えて土壤水分条件を調節したが, その土壌水分の変化は第 1 図に示 すとおりである。1，2，3 区は比 較的水分条件の変動が小さかった が，4,5 区は変動が大きかった。 試験期間中における種子位置の含 水比の平均値は 1 区: $54.6 \pm 1.9$ $\%(\mathrm{pF} 1.5), 2$ 区 : $41.2 \pm 1.3 \%$ (pF 1.9), 3 区: $28.3 \pm 1.9 \%$ (pF 3.3), 4 区: 16.8 $4.1 \%$ ( $\mathrm{pF} 4$ 以上), 5 区: $13.7 \pm 2.5$ $\%$ (pF 5 以上) で, 4, 5 区はか なり乾燥条件であった。

出芽の状況は第 1 表に示すとおりである。なお，力ヤ ツリグサについては, 各区とも出芽率が著しく低かった ので, 試験から除外した。第 1 表の出来率は, 含水比の 最も高い 1 区の出芽率を 100 とした比率で示した。供試 植物の出芽率はラッカセイ, ダイズ，トウモロコシが 1 , 2 区で同等ないしは 2 区の方がむしろ高い值を示した が，その他の植物では 1 区で最も高い結果が得られた。 2 区では前述した 3 種を除いて各植物とも出芽率が低下 し, 特にスベリヒュ, オヒシバ, グリーンパニックの低 下が著しく，1区に対して有意に劣った。また，ローズ グラス，シコクビェも有意な低下がみられた。3区では 雑草と牧草, さらに作物の中でグレインソルガムとシコ クビェは 1 区の $10 \%$ 以下と著しい低下がみられ，この 区における土壌水分条件がこれら植物の出芽に対しほぼ 限界的な值であることを示唆していた。一方，作物はグ

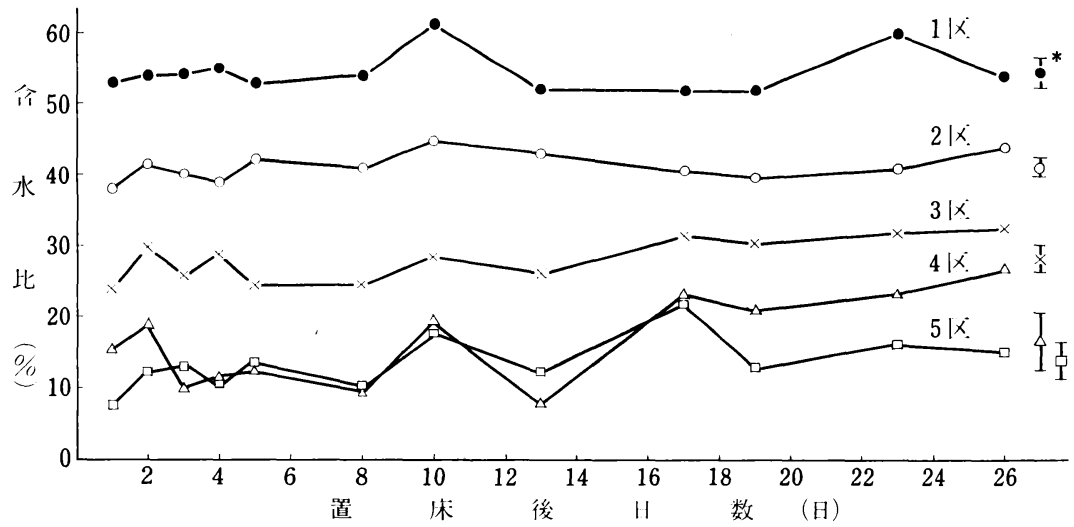

第 1 図 種子位置に打ける土壤水分の推移（試験 1) 注） *: 試験期間中の平均値とその $95 \%$ 信頼限界
レインソルガムとシコクビエを除いて 3 区の低下が比較 的少なく, ラッカセイ，ダイズは 1 区の $50 \%$ かそれ以 上, 陸稲も $20 \%$ を示し, トウモロコシは $104 \%$ とまっ たく低下がみられなかった。 4,5 区では出芽率はさら に低下したが，その傾向は 3 区と同様で普通作物で低下 が少なく, 雑草と牧草ではほとんど出来がみられなかっ た。

平均出芽日数についてみると, 植物間で若干変動がみ られるが，概して土袞水分の低下とともに長くなった。 特に雑草と牧草については出芽率が著しく低下した 3 , 4 区のメヒシバを除く各区において，また，作物につい ては 4,5 区において平均出芽日数の著しい増加がみら れた。

[試験 2]種子による吸水力の差をみるため, グル コースモル濃度を変えることにより浸透圧の異なる発芽

床をつくって発芽試験を行 い,その結果を第 2 表に示 した。発牙率についてみる と, 雑草と牧草は各草種と もモル濃度の増加に伴ない 発芽率は低下し，対照区の 0 モル区に対し，0.2 モル 区においてはシロザ，スべ リヒユ，オオイヌタデを除 いて著しい低下がみられ， イヌビユ，オヒシバ，ロー ズグラス，グリーンパニッ クでは全く発芽がみられな かった。0.4モル区におい 
第 2 表 植物の発芽々初期生育に及ぼすグルコース モル濃度の影響（試験 2 ）

\begin{tabular}{|c|c|c|c|c|c|c|}
\hline 種 & $\begin{array}{l}モ \text { 濃 } \\
\text { 度 }\end{array}$ & $\begin{array}{c}\text { 発芽率 } \\
(\%)\end{array}$ & $\begin{array}{l}\text { 草丈・ } \\
\text { 主茎長 } \\
(\mathrm{cm})\end{array}$ & $\begin{array}{l}\text { 最長根 } \\
\text { 長 } \\
(\mathrm{cm})\end{array}$ & 根 数 & $\begin{array}{l}\text { 生体重 } \\
(\mathrm{mg})\end{array}$ \\
\hline \multirow{2}{*}{ × } & 0 & 46 & 1.6 & 3.2 & 1.8 & 4.3 \\
\hline & 0.2 & 2 & 0.7 & 1.0 & 0.5 & - \\
\hline \multirow{3}{*}{ 口 ザ } & 0 & 16 & 0.7 & 1.1 & 1.0 & 1.0 \\
\hline & 0.2 & 12 & 0.6 & 0.5 & 1.0 & 1.7 \\
\hline & 0.4 & 2 & 0.5 & 0.2 & 0.8 & - \\
\hline \multirow{5}{*}{ オオイ タ デ } & 0 & 7 & 2.7 & 3.3 & 2.7 & 12.4 \\
\hline & 0.2 & 3 & 0.7 & 3.4 & 4.4 & 3.8 \\
\hline & 0.4 & 2 & 0.6 & 1.0 & 3.8 & 8.0 \\
\hline & 0.6 & 1 & - & - & - & 一 \\
\hline & 0.8 & 1 & - & - & - & - \\
\hline \multirow{3}{*}{ 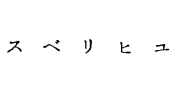 } & 0 & 86 & 0.5 & 1.0 & 1.0 & - \\
\hline & 0.2 & 46 & 0.6 & 0.6 & 1.0 & 一 \\
\hline & 0.4 & 1 & 0.1 & - & - & - \\
\hline \multirow{2}{*}{ カナッリグサ } & 0 & 11 & 1.7 & 0.6 & 2.7 & 0.7 \\
\hline & 0.2 & 2 & 0.6 & 0.4 & 1.7 & - \\
\hline イ ヌ ビ & 0 & 31 & 2.5 & 1.2 & 1.1 & 6.0 \\
\hline オ $\quad$ $\quad$ : & 0 & 5 & 1.0 & 1.6 & 2.2 & 2. 0 \\
\hline ローズグラス & 0 & 17 & 1.5 & 1.2 & 1.1 & 1.7 \\
\hline グリーンパニック & 0 & 6 & 2.2 & 1.3 & 1.4 & 2.0 \\
\hline \multirow{4}{*}{ 陸 } & 0 & 43 & 2.4 & 4.6 & 5.5 & 58 \\
\hline & 0.2 & 42 & 1.4 & 1.8 & 1.0 & 45 \\
\hline & 0.4 & 28 & 0.6 & 1.4 & 1.0 & 39 \\
\hline & 0.6 & 2 & - & 0.1 & 1.0 & 36 \\
\hline \multirow{4}{*}{ ラッカ $七$ カ } & 0 & 75 & & 4.3 & & 1,710 \\
\hline & 0.2 & 79 & & 1.5 & & 1,298 \\
\hline & 0.4 & 51 & & 0.6 & & 1,120 \\
\hline & 0.6 & 4 & & 0.1 & & 1,333 \\
\hline \multirow{3}{*}{ ダ $\quad 1 \quad \pi$} & 0 & 91 & 6.9 & 8.0 & 15.8 & 1,108 \\
\hline & 0.2 & 77 & - & 1.9 & 1.0 & 652 \\
\hline & 0.4 & 42 & - & - & - & - \\
\hline \multirow{4}{*}{ トウモロコシ } & 0 & 94 & 8. 1 & 17.6 & 6.5 & 1,177 \\
\hline & 0.2 & 93 & 1.9 & 2.5 & 4.7 & 570 \\
\hline & 0.4 & 93 & 1.3 & 1.9 & 3.9 & 474 \\
\hline & 0.6 & 33 & 0.4 & 1.4 & 2.0 & 418 \\
\hline \multirow{5}{*}{ グレインソルガム } & 0 & 94 & 3.1 & 5.4 & 3.0 & 77 \\
\hline & 0.2 & 95 & 1.5 & 1.0 & 0.2 & 48 \\
\hline & 0.4 & 95 & 0.3 & 0.5 & 1.0 & 38 \\
\hline & 0.6 & 47 & 0.4 & 0.5 & 1.0 & 48 \\
\hline & 0.8 & 19 & 0.2 & 0.3 & 1.2 & 42 \\
\hline \multirow{4}{*}{$シ コ ク ヒ ゙ エ$} & 0 & 59 & 2.1 & 4.6 & 1.9 & 13.0 \\
\hline & 0.2 & 51 & 1.4 & 1.3 & 0.9 & 5.5 \\
\hline & 0.4 & 29 & 0.6 & 0.1 & 0.4 & - \\
\hline & 0.6 & 1 & - & 0.1 & 一 & - \\
\hline
\end{tabular}

注 1）*全く発芽しなかったモル濃度は省略した。

2）根数と生体重は 1 倜体当たりである。

てはシロザ，オオイヌタデ，スベリヒユで $1 \sim 2$ 本の発 芽がみられた以外全く発芽せず， $0.6 \sim 0.8$ モル区では オオイヌタデが 1 本発牙したのみであった。これに対し て普通作物はモル濃度の増加による発芽率の低下がそれ
ほど大きくなく，0.2 モル区ではダイズ以外はほとんど 低下がみられなかった。0.4 モル区でもトウモロコシと グレインソルガムは対照区と差がなかったが，それ以外 の作物は対照区の 46〜68\%に低下した。0.6モル区で はグレインソルガムが詨照区の約 $50 \%$, トウモロコシ は約 $35 \%$ であったが，それ以外の作物は $2 \sim 5 \%$ と著 しく低下し，ダイズでは発芽がみられなかった。0.8モ ル区ではグレインソルガムのみに発芽がみられ, 他は全 く発芽しなかった。

次に草丈・主茎長についてみると, 各植物とも概して モル濃度の増加に伴い抑圧された。普通作物で発芽率が 低下しない 0.2 モルの条件でも抑圧がみられ，特にトウ モロコシで著しく，またダイズは全く伸長がみられなか った。最長根長もモル濃度の増加で伸長が妨げられた が, 概して草丈・主䒱長の場合よりも, より強く抑制さ れた。根数, 生体重についてみると, 区間で若干のばら つきがみられたが，モル濃度の増加により減少した。

〔試験 3 ]出芽に対する限界的な土塞水分条件を明確 にするため, 含水比を変えて試験した結果を第 3 表に示 した。出芽率についてみると, 各植物とも含水比の低下

第 3 表 植物の出芽と初期生育に及ぼす土壤水分条 件の影響（試験 3 ）

\begin{tabular}{|c|c|c|c|c|c|c|c|c|}
\hline $\begin{array}{l}\text { 項 } \\
\text { 目 }\end{array}$ & 含 水 比 & $\begin{array}{l}x ヒ \\
\text { シை }\end{array}$ & $\begin{array}{l}\text { スペリ } \\
\qquad ユ\end{array}$ & $\begin{array}{l}\text { イヌ } \\
ヒ ゙ Z\end{array}$ & 陸稲 & $\begin{array}{l}\text { ダイ } \\
\text { ズ }\end{array}$ & $\begin{array}{l}\text { トゥモ } \\
\text { ロコシ }\end{array}$ & $\begin{array}{l}シ コ ク \\
\text { ビェ }\end{array}$ \\
\hline \multirow[b]{2}{*}{ 出 } & $20^{\%}$ & $\begin{array}{l}\% \\
0\end{array}$ & $\begin{array}{l}\% \\
7\end{array}$ & $\begin{array}{l}\% \\
0\end{array}$ & $11 \%$ & 23 & $\begin{array}{c}\% \\
83\end{array}$ & $12 \%$ \\
\hline & 25 & 30 & 70 & 14 & 87 & & & 60 \\
\hline 芽 & 30 & 100 & 100 & 100 & 100 & 100 & 100 & 100 \\
\hline \multirow[t]{2}{*}{ 率 } & l. s. d. $5 \%$ & 50 & 16 & 9 & 9 & 4 & n.s. & 21 \\
\hline & $30 \%$ 区の值 (\%) & 38.0 & 76.3 & 74.3 & 74.6 & 86.7 & 100.0 & 51.3 \\
\hline \multirow{5}{*}{$\begin{array}{l}\text { 草 } \\
\text { 主 } \\
\text { 主 } \\
\text { 㝨 } \\
\text { 辰 }\end{array}$} & 20 & - & 45 & - & 57 & & & 42 \\
\hline & 25 & 70 & 81 & 68 & 91 & & & 92 \\
\hline & 30 & 100 & 100 & 100 & 100 & & & 100 \\
\hline & 1. s. d. $5 \%$ & 32 & 7 & 14 & 25 & & & 28 \\
\hline & $30 \%$ 区の值 $(\mathrm{cm})$ & 5.6 & 2.2 & 4. 4 & 16.1 & & & 7.3 \\
\hline \multirow{3}{*}{ 生 } & 20 & - & 0 & - & 27 & & & 24 \\
\hline & 25 & 64 & 72 & 54 & 60 & & & 61 \\
\hline & 30 & 100 & 100 & 100 & 100 & & & 100 \\
\hline \multirow[t]{2}{*}{ 重 } & l.s.d. $5 \%$ & 59 & 26 & 23 & 14 & & & 26 \\
\hline & $30 \%$ 区の值 $(\mathrm{mg})$ & 17 & 10 & 24 & 137 & & & 53 \\
\hline
\end{tabular}

注）各項目とも含水比 $30 \%$ 区を 100 とする比率で示した。

により低下したが，トウモロコシでは含水比 $30 \%$ 区に 対して $20 \%$ 区で有意な低下はみられず，陸稲，ダイズ， シコクビェとも $10 \%$ 以上の出芽率を示した。これに対 して雑草は低下が著しく, 含水比 $25 \%$ 区では $30 \%$ 区 の 14 70\%の出芽率を示したが，20\%区ではメヒシ バ，イヌビユが全く出芽せず，スベリヒユも $30 \%$ 区の $7 \%$ に低下した。

生育についてみると, 草丈・主茎長, 生体重とも乾燥条 

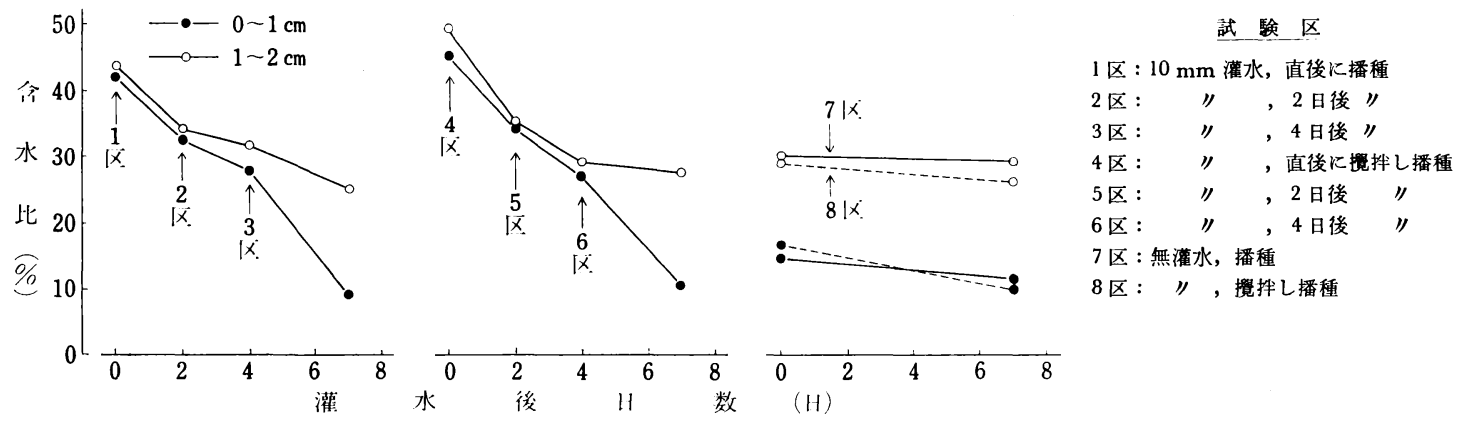

第 2 図 灌水後の日数の経過に伴 5 土壤水分の変化（試験 4)

件で減少するが, 試験 2 の結果と対照的に, 概して出芽 率の低下に比べて影響が小さい傾向がみられた。

[試験 4] 固場に近い条件で土壌水分条件の変化と種 子の出来との関係について試験した結果を第 2 図と第 4 表に示した。水分条件の変化を第 2 図でみると, 土畩の 擋拌の影響は小さく，擋拌の有無にかかわらず雑草種子 の播種位置である $0 \sim 1 \mathrm{~cm}$ 層では，灌水区において灌 水直後は含水比 $42 \sim 45 \%$ であるが， 2 日後には $32 \sim 34$ \%，4 日後には $27 \sim 28 \%$ ，そして以後の低下が著しく， 7 日後には $9 \sim 11 \%$ に達した。無灌水区では播種直後 は 15 17\%，7 日後では 10〜11\%に低下した。一方， 作物の播種位置である $1 \sim 2 \mathrm{~cm}$ 層では，灌水区におい て，灌水直後は 44 49\%，2 日後では 34 35\%，4 日 後では $29 \sim 31 \%$ と $0 \sim 1 \mathrm{~cm}$ 層よりわずかに高い程度 であったが，4 日以降の低下は䋧やかで，7 日目でも $25 \sim 27 \%$ と $0 \sim 1 \mathrm{~cm}$ 層よりかなり高い含水比を示し た。無灌水区では，播種直後は 28３0\%，7 日後では 26〜29\%とほとんど低下がみられず，7 日後の含水比 は灌水区とほとんど差がなかった。

次に出芽について第 4 表でみると, 雑草種子は全体に 出芽率が低いが，灌水直後の播種区 $(1,4$ 区) に対して 播種期が遅れるにしたがい出芽率は著しく低下し，4 日 後の播種区 $(3,6$ 区) では 3 区のスベリヒユを除いて全

第 4 表 土壤水分条件々出芽率（試験 4 ）

\begin{tabular}{|c|c|c|c|c|c|}
\hline 試 験 区 & メヒシハ: & $\begin{array}{lll}x & \text { ○े } \\
\text { 匕 }\end{array}$ & 陸程 & ダイス & $\begin{array}{l}\text { グレイン } \\
\text { ソルガム }\end{array}$ \\
\hline 1. 灌水 0 日 & 7.0 & $13.0^{\%}$ & 92.7 & 86.7 & 86.0 \\
\hline 2. $॥ 2 》$ & 1.3 & 3.7 & 73.3 & 23.3 & 84.0 \\
\hline 3. & 0 & 2.0 & 23.3 & 31.7 & 23.3 \\
\hline 4. 灌水 0 日稂挥 & 4.0 & 40.3 & 94.0 & 81.7 & 86.7 \\
\hline 5. $\gg 2 》$ & 0 & 1.0 & 70.0 & 27.5 & 31.0 \\
\hline 6. " 4 " & 0 & 0 & 22.0 & 43.3 & 24.7 \\
\hline 7. 無灌水 0 日 & 0 & 0 & 43.3 & 38.3 & 48.7 \\
\hline 8. $》$ 拌眮 & 0 & 0 & 42.7 & 56.7 & 38.7 \\
\hline l.s.d. $5 \%$ & n. s. & 21.6 & 47.8 & 40.0 & 42.6 \\
\hline
\end{tabular}

く出芽がみられなかった。また無灌水区では雑草種子は 全く出芽しなかった。作物種子についてみると, 灌水後 播種期が遅れるほど出芽率は低下したが，灌水 4 日後の 播種区でも陸稲が 22〜23\%，ダイズが 32〜 43\%，グレ インソルガムでは 23 25\% の出来率を示した。また無 灌水区でも灌水 4 日後播種区に劣らない出芽がみられ た。

\section{考察}

試験 1,3 の結果，若干の変動はあるが，本試験の条 件では土壤水分条件の高い方が出芽率が高く，また平均 出芽日数も短かった。水分条件の低下とともに出来率は 低下し, 平均出芽日数も増加するが, 特に出芽率の低下 は作物より雑草と牧草で著しかった。すなわち試験 1 に よると, 雑草と牧草は含水比 $28.3 \%(\mathrm{pF} 3.3)$ の条件 では $54.6 \%(\mathrm{pF} 1.5)$ の条件に比べて出牙率がその $0 \sim 4 \%$ に低下したのに対し, 作物では低下が少なく, 含水比 14 17\%の条件でもかなりの出芽がみられた。 試験 3 の結果も同様の傾向であったが, 雑草の出芽は含 水比 $25 \%$ でもかなりみられ，20\%でもスベリヒュが 出芽するなど, 試験 1 に比べると若干低い水分条件でも 出芽を示す傾向がみられた。これは試験方法の違いによ るものと考えられる。すなわち試験 1 において種子の吸 収する水は毛管水であり, 種子は毛管の負圧に抗して吸 収しなければならないのに対し, 試験 3 では, 土壌水分 は毛管を形成せず土壌粒子のまわりに層として存在す るか, 球状で存在しており, 種子にとって耄管水より吸 収しやすいものと考えられる。したがって試験 1 より試 験 3 の方で若干低い水分条件でも出来がみられたもので あろら。いずれにしても試験 1，3の結果から，出芽のた めの限界的な土䁃水分条件は，作物では含水比で $20 \%$ 前後, 雑草と牧草では 25 30\% と推定された。松原ら ${ }^{4}$ によると, ダイコン, ナタネ，ヒマワリ種子の発来限界 土壤水分は火山灰土壌において永久萎调点付近 (含水比 
約 $25 \%$ ）であるが，ニンジンはこれらよりかなり高い として抢り，種類により限界土壤水分に差異のあること を認めている。

以上のように，植物間に扔いて土壤水分と出芽率との 関係に差異が生ずるが，その原因として，種子の吸水力 が関与していると考えられるので, 試験 2 で検討した。 その結果, グルコースモル濃度すなわち浸透圧の増加に 伴う種子の発芽率の低下は作物より雑草, 牧草の方が著 しかった。すなわち種子の吸水力は雑草, 牧草より作物 の方が大きく, 種子の出芽と吸水力とは関連が深いこと が明らかとなった。この点は岡本ら ${ }^{5,6)}$, Hoveland ${ }^{2)}$, 中沢 ${ }^{8)}, \mathrm{PARMAR} ら^{7)}$ を初め多くの報告で指摘されて いる。なお，吸水力の差異が生ずる原因については，本 試験では解明していないが，岡本ら ${ }^{5)}$ は種子の大きさの 違いが関与していると報告している。本試験で供試した 種類では雑草, 牧草より作物種子の方が種子重が大きい （第 1 表）ので, 岡本らの指摘と大略一致するが, 作物 種子の中で種子の大きいダイズより，小さいグレインソ ルガムの方が吸水力が大きい（第 2 表）など，必ずしも 種子重だけで説明しきれない点もある。この点は, 中沢 $ら^{8)}$ も，土㙵溶液の濃度が発芽に及ぼす影響が小さい作 物としてトウモロコシ, ソルゴーなど, 中程度の作物と して陸稲, ラッカセイなど, 大きい作物としてダイズ, ダイコンなどとしており, 本試験の結果とほぼ一致して いるが，種子重と吸水力とは必ずしも対応していない。 すなわち種子重以外にその種子が持つ遺伝的特性も関与 しているのであろう。なお，吸水力の最も大きいグレイ ンソルガムが乾燥条件に扔ける土㗧で他の作物上り出芽 率の低下が著しいなど，その原因については今後検討し なければならない。

耕地雑草の土壤水分に対寸る適応性については荒井 ら ${ }^{1)}$ の報告があり, 耕地雑草を水生, 湿生, 乾生に分類 し, さらに乾生雑草を乾生 (湿), 乾生 (乾)に分けてい る。本試験で供試した雑草は烟雑草であるからほとんど が乾生（乾）にあたるが, イヌビユは乾生（湿), カヤ ッリグサは湿性とされている。本試験の結果の範囲で は, 雑草間の差異は各試験で若干の違いもあり, 明確で なかった。またシロザとオオイヌタデが比較的含水比の 低い条件でも出芽し，また吸水力も強い傾向がみられ た。山本ら ${ }^{10}$ は, タデ類は土壤水分に対してメヒシバや オヒシバに比べ鈍感であると報告しているので，そうし た特性によることも考えられるが，本試験では発芽試験 の前に行った休眠打破処理 (低湿, 湿潤条件) の期間中 に既に吸水していたことも関与していると考えられる。 暖地型牧草種子の発芽に関しては, 岡本ら ${ }^{5,6)}$ がグ
リーンパニックとローズグラスはシコクビエ, ソルガム 上り吸水力が小さく, 乾燥条件に扔ける出芽率の低下が 著しいとしており，これは本報告とよく一致している。 乾燥条件に扔いては，出芽率の低下だけでなく，生育 も著しく抑制される。試験 2 では草丈・主茎長より根の 伸長がより強く抑制され，また発芽率の低下しない条件 でも生育は著しく抑制されたが, 試験 3 では出芽率の低 下より生育への影響が小さいなど, 対照的な結果が得ら れた。その原因については明確でないが，これらの点は 植物の定着にとって重要であり, 土壤条件における根の 発達との関連でさらに検討が必要であろう。

試験 4 亿おいて, 圃場に近い条件で出芽と土壤水分と の関係について検討した。その結果，土壤表面とそのわ ずか下層における水分条件の変化は大きな差異があり, それが種子の出芽に著しい影響を及ぼすことが明らかと なった。雑草種子は一般に発生深度が浅く, $0 \sim 1 \mathrm{~cm}$ 層からの発生が最も多い9)が, 試験 4 の結果から明らか なように, $0 \sim 1 \mathrm{~cm}$ 層の土壤水分は灌水数日後に含水 比 $30 \%$ かそれ以下に低下寸る。したがって灌水 4 日後 に $0 \sim 1 \mathrm{~cm}$ 層に播種した雑草種子は全く出芽しないか, 出芽してもわずかであった。一方, $1 \sim 2 \mathrm{~cm}$ 層では含 水比 $30 \%$ までは速やかに低下寸るが，それ以降の低下 が緩やかで含水比 $25 \%$ 前後で経過し, 無灌水区でも 25 $\%$ 以下には低下しなかった。したがって $1 \sim 2 \mathrm{~cm}$ 層に 播種した作物種子は灌水 4 日後の区と無灌水区でも 20 $\%$ 以上の出芽を示した。また, 以上の結果は, 前述した 出芽の限界的な土壌水分条件を裏付けるものであった。 なお, 擋拌の有無によって土壤水分に差が生じなかった のは, 擋拌時に比較的土壤水分が高かったこと, 擋拌後 整地を兼ねて鎮压したことなどが関与していると考えら れる。

圃場において作物種子は一般に覆土されるため水分条 件は比較的安定しているのに対し, 雑草種子は非常に不 安定な条件におかれている。本試験の結果, 地表面にお いては，降雨後数日で雑草種子の出芽にとって限界的な 土壤水分条件に低下寸る可能性の大きいことが明らかと なった。一般に乾燥条件においては播種後土壤処理剂の 効果が不安定であることが指摘されているが，それには 除草剤の作用力の低下だけでなく，この上らな雑草種子 の出芽の特性が関与していると考えられる。効果的な雑 草防除技術を確立するためには，以上のような作物と雑 草種子小土壌水分条件に対寸る反応について十分理解し ておく必要があろう。 
摘要

主要な畑雑草種子の発芽および出芽と水分条件との関 係について, 普通作物, 牧草種子と比較, 検討した。

1）土壤水分条件を変えて出芽との関係を検討した結 果, 各供試植物とも含水比 $54.6 \%(\mathrm{pF} 1.5)$ の条件で 最も出芽率が高く, 含水比の低下とともに出芽率も低下 し，また平均出芽日数が増加した。土壌水分の低下によ る出芽率の減少は普通作物より雑草と牧草で著しく, 出 芽のための限界的な土袞水分条件は, 含水比で作物では $20 \%$ 前後, 雑草と牧草は 25 30\% と推定された。な お, 本試験の範囲では, 雑草間の異差についてははっき りしなかった。

2）土壌水分の違いによる出来率の差異は種子の吸水 力が関与しており, グルコースモル濃度により浸透圧を 変えて試験した結果, 種子の吸水力は作物で大きく, 雑 草と牧草は小さかった。また, 浸透圧の高い条件では草 丈・主茎長や根の伸長などの生育も抑制された。

3）圃場において, 地表面 ( $0 \sim 1 \mathrm{~cm}$ 層) の土壤水
分は, 灌水後数日で含水比 $25 \sim 30 \%$ 以下に低下し，雑 草種子の出芽限界以下になるが，それより下層（1２ $\mathrm{cm}$ 層) では比較的安定しており，種子位置のわずかの 違いが出芽にとって重要な要因であることが明らかとな った。

\section{引 用 文 献}

1）荒井正雄 - 宮原益次 - 横森秀文: 関東東山農試研報 8 , $56 \sim 62$ (1955).

2) Hoveland, C. S. and G. A. Buchanan: Weed Sci. 21, 322 324 (1973).

3）岩田岩保 - 白坂 進: 雑草研究 13, 42 47 (1972).

4) 松原尚生 - 杉山直儀：園学雑 34 (2), 29 36 (1967).

5）岡本恭二 ・ 川竹基弘 - 堀内慎一：日草誌 21 (1), 16 20 (1975).

6）岡本恭二 - 堀内慎一：日草誌 21 (1), 21 25 (1975).

7) Parmar, M. T. and R. P. Moore : Agron. J. 58, $391 \sim 392$ (1966).

8）中沢秋雄・四方俊一：農事試研報 7, 35 53 (1965).

9) 高林 実. 中山兼徳：雑草研究 21 (別), 39 40 (1976).

10）山本泰由.大庭寅雄: 雑草研究 21 (1), 20 24 (1976).

(1979 年 10 月 15 日受理)

\title{
Effects of Soil Moisture on Germination and Emergence of Seeds of Upland Weeds
}

\author{
Katsuyoshi Noguchi and Kanenori Nakayama \\ Central Agricultural Experiment Station, Ministry of Agriculture, \\ Forestry and Fisheries, Yatabe, Ibaraki 305
}

\section{Summary}

This experiment was conducted to clarify the effects of soil moisture on germination and emergence of seeds of upland weeds, grasses and common crops. The plants used in this experiment were large crab-grass (Digitaria adscendens Henr.), common lamb's quarters (Chenopodium album L.), Polygonum nodosum Pers., common purslane (Portulaca oleracea L.), Chufa (Cyperus microiria Steud.), livid amaranth (Amaranthus lividus L.), goose grass (Eleusine indica Gaertn.), Rhodes grass (Chloris gayana Kunth), green panic (Panicum maximum), upland rice (Oryza sativa L.), peanut (Arachis hypogaea L.), soybean (Glysine max (L.) Merill), corn (Zea mays L.), grain sorghum (Sorghum bicolor (L.) Moench) and African millet (Eleusine coracana (L.) Gaerth).

1) Seeds were setted in the soils having different soil moisture contents. Each plants showed the highest emergence percentage at the condition of $54.6 \%$ ( $\mathrm{pF} 1.5)$ of soil moisture percentage on dried soil basis. Emergence percentage reduced and average length of time for emergence increased with decreased soil moisture percentage. The reduction of emergence percentage of weeds and grasses with decreased soil moisture percentage were more remarkable than that of common crops. The minimum soil moisture content allowing emergence of common crops was estimated about $20 \%$ of soil moisture percentage and that of weeds or grasses was estimated $25 \sim 30 \%$. The difference of emergence with decreased soil moisture among weeds was not clear in this experiment. 
2) The moisture absorbing power of seeds was related to the difference of emergence percentage with different soil moisture contents. Glucose was mixed with distilled water to obtain desired osmotic presseres, and seeds were germinated in water solutions having different osmotic presseres. From the results of this experiment, the moisture absorbing power of seeds was large in common crops and was small in weeds and grasses. The growth of plants was depressed at the condition of high osmotic presseres.

3) The soil moisture percentage of the surface of the ground $(0 \sim 1 \mathrm{~cm})$ fell to $25 \sim 30 \%$ after several days of watering in the fields, and this was below the minimum soil moisture contents allowing emergence of weeds. But, soil moisture in lower layer $(1 \sim 2 \mathrm{~cm})$ was relatively stable, so it was clear that a little difference in location of seeds was the important factor for emergence of seeds. 